\title{
$\mathrm{U}$
}

\section{'Una Favola'}

Fable of 1821 (see MYRS vi.li-ii), written in Italian, of a youth's encounters with personified abstractions including Life, Love and Death. The first published text appeared in 1862. The Huntington notebook draft (MYRS vi.206-33) includes revisions by Emilia *Viviani (see MYRS vi.l); probably her corrections explain why the fair copy in the Bodleian (BSM xxi.250-63) is in better Italian than the draft. The story was almost certainly intended for Viviani and the omission of its final passage may, Mary A. Quinn argues, be an attempt to minimize offence to Mary *Shelley: the references to jealousy 'could be construed as a fictionalized recasting of [her] response to Shelley's infatuation with ... Viviani' (MYRS vi.li).

'Una Favola' belongs to the tradition of *Dante and of *Petrarch's Trionfi. It also re-uses elements of the poet's quest in Alastor and looks forward (Rognoni 1807) to the progression of the protagonist in Epipsychidion.

\section{'Unfinished Drama'}

Fragmentary verse drama, begun probably in February 1822. It was 'undertaken for the amusement of the individuals who composed our intimate society' (1839 iv.168). According to Mary *Shelley's 'sketch of the story' (1839 iv.168) an Enchantress 'becomes enamoured of' a Pirate who 'for awhile returns her passion' before going back to his 'mortal love'. There are speeches by the Enchantress and a Spirit and part of a scene involving the mortal woman and an Indian youth who is in love with her. As Crook (2009), p. 309, notes, faithlessness would clearly have been one of the main themes of the play. Cox (2006), p. 65, suggests that it owed something to the Sanskrit drama Sakuntala'.

Further reading: Mulhallen (2010).

\section{'Upon the Wandering Winds'}

Sonnet 'concerned ... with the relation of thought to the objects of thought' (PS i.520). It is one of the poems in the Scrope *Davies notebook, written probably on or about 1 July 1816 (PS i.520) and first published in 1978. 